\title{
Retranslation: A Comparative Study of Two English Translations of Vimalakirti Sutra
}

\author{
Tianyu Lei \\ Department of East Asian Studies, University of Arizona, Tucson, AZ 85721, USA
}

\begin{abstract}
Retranslation is a widespread phenomenon which has been discussed and studied by translators and Translation Studies scholars for years. The meaning of retranslation lies in its difference (not necessarily improvement) from the previous ones, which means retranslation would provide something new both to readers and translators. Through the prism of the theory of retranslation, the study examines two English translations of Vimalakīti Sutra, showcasing that although Burton Watson's rendition is recognized as one in high quality, John McRae's retranslation still helps us to contemplate on how to keep balance between literary interest and religious interest during the process of translating sacred texts.
\end{abstract}

Index Terms-retranslation, Vimalakīrti Sutra, Burton Watson, John McRae

\section{INTRODUCTION}

Retranslation is a widespread phenomenon which has been discussed and studied by translators and Translation Studies scholars for years (Feng, 2014). Generally speaking, "retranslation" usually has three denotations: the first connotation refers to a "second-hand" translation, which means the translation is based on a third language edition, a language other than either the source language or the target language; the second denotation could be concluded as a "back translation" which means a target-language text that is translated back into the language of the source text when the original text is lost (Feng, 2014). The phenomenon of "back translation" does not only happen in the literary world but also in the religious world where the situation is much more complicated. A good example of this in the religious world might the famous Heart Sutra (Nattier, 1992). The most relevant and important denotation of retranslation to this study is "either the act of translating a work that has previously been translated into the same language, or the result of such an act."(Gürçağlar, 2009)

\section{GENERAL REMARKS ON THE THEORIES OF RETRANSLATION}

The "retranslation hypothesis" was first proposed by Antoine Berman in 1990. He claimed that the translation of literary works is an "incomplete act", and only through retranslations can it strive for completion (Feng, 2014). The most frequently retranslated works are sacred texts and literary works (Brownlie,2006). Some great literary works, such as Tu Fu's (712-770) or Su Shi's (1037-1101) pomes, are translated again and again, and the purposes of those repetitive renditions might be improvement or correction. However, when it comes to religious works, the intentions turn to be more complex. For example, confronting the flood of numbered lists of categories, ideas and so forth (of which Indian thinkers were so much enamoured) that came to China in the wake of Buddhism, some earliest Buddhist missionaries used the method of "categorizing concepts" (geyi 格義) to translate Buddhist sutra(Mair,2012), which was criticized by the later translators for the misuse of the Taoist terms and concepts in Buddhist translations. Therefore, a large number of new translations emerged during the Sui and Tang Dynasties (581-906) due to this reason. In other cases, retranslation emerged when more "authentic" editions of original texts were discovered or transmitted to China (Fang, 2007). In this section, I intend to introduce some theories of retranslation from the following three perspectives:1) the necessity, 2) motives, and 3) the relationship between the early translation (not necessarily the first one) and later translations.

\section{A. Necessity}

Although retranslation has long been criticized as being "wasteful," some scholars and literary critics believe that a retranslation is necessary even if a good translation of the same work already exists, as the re-translator could benefit from the old translation and try to achieve "perfection" (Feng, 2014). Despite the fact that the meaning of "perfection" is still needed to be further discussed, it vividly shows that the necessity of retranslation lies in its difference (not necessarily improvement) from the previous ones, which means retranslation would provide something new both to readers and translators.

\section{B. Motives}

Retranslation is completed by the translator, the publisher or the scholar. Most of time, when later translators are not satisfied with the pre-existing renditions, they embark on their own versions. The reasons of this "discontent" might be 
divergent personal appreciation, translation strategies, even the different foci.

\section{Relationship between the Early Translation and Later Translations}

Venuti (2003) declared that retranslations "justify themselves by establishing their difference from one or more previous versions." He also argued that the differences are guided more by social or ideological premises than by linguistic or literary lack in the previous translations, which is especially the case for the translations of Buddhist texts (Venuti, 2003).

Another noteworthy difference is that early translations might be more domesticated or target-oriented, while the later translations tend to maintain a cultural distance between the translation and its source because of their reflection on the previous ones (Feng, 2014).

\section{The Comparative Study of Two English Translations of Vimalakīrti Sutra}

Two English translations of Vimalakirti Sutra will be investigated to verify the foregoing theories of retranslation. Due to the great length and extensiveness of Vimalakirti Sutra, I select Chapter 6 as the center of my discussion because of its dramatic plot and the tension within the conversations among four main characters.

\section{A. Vimalakìrti Sutra and Its Translations}

Vimalakirti Sutra (Weimojie jing 維摩詰經) is one of the most important sutras of Chinese Buddhism, which exerts profound influence on literature and art of East Asia. It was composed conceivably by around $100 \mathrm{CE}$, certainly by the early 3rd century (Silk, 2015). Doctrinally, the nuclear of Vimalakirti Sutra derived from the Perfection of Wisdom (Prajñāpāramitā) literature. Spiritually, the demonstrative quality of Vimalakīrti’s silence, and the vivid interaction between him and other great disciples and Bodhisattva, hinted at a deep contact with the later development of the Chinese Chan school (McRae, 2004). However, like many other Indian Mahayana sutras, the Indic language edition of this scripture had been lost for centuries (Nattier,2000). In addition, there is no evidence that a single Indian commentary on the text ever existed. As Nattier concluded, it might not be a popular text in India and it is also hard to gauge the degree of influence exerted by this text in India, which is in sharp contrast to the situation of East Asia (Nattier, 1992).

It is said that Vimalakirti Sutra has been translated in to Chinese no fewer than eight times, of which three versions are extant: those completed by Zhiqian 支謙(?-?), Kumārajīva (344-413), and Xuanzang 玄奘(602-644). Kumārajīva's version is widely acknowledged to be the best one, both as a Buddhist sutra and a literary work. Thus, it is not surprising that three of the six published English translations (one from Sanskrit version, two from Tibetan version, and three from Chinese version) are renditions of Kumārajīva's version. In this study, I am going to discuss two of these three renditions which are translated from the Chinese text_— Burton Watson's version and John Mcrae's rendition.

\section{B. Motives for Retranslation and Relation between the Two Translations}

Watson's version is not the first English translation, but it is the most popular and influential one (Nattier, 1992). Nevertheless, as Watson pointed out in the preface, like his translation of Lotus Sutra, this translation was intended primarily for readers who have no special background in Buddhist studies. Carrying such intension, he deliberately omitted detailed information about the Sanskrit terminology and the thought and background of the sutra (Watson, 1997), which, in McRae's eyes, eliminated a great deal of its intrinsic religious interest (2004). In other words, the "discontent" with the previous rendition (Watson's version as to say) motivated McRae to start his own translation.

The main difference between these two renditions is guided by ideological premise. As simplified as Watson's translation, his targeted audiences are ordinary people or readers who have no special background in Buddhist studies. Other than a scholarly artifact, his translation is more of a literary work. By contrast, McRae paid most attention to the religious interest within translation. His targeted audiences are scholars or at least people who possess knowledge in Buddhist studies_ — his translation is a serious academic work.

Another difference lies in the extent of readability. As an early translation, Watson's version is motivated by a concern for higher levels of readability (1997), which makes his usage of language more domesticated. On the contrary, reflecting on Watson's work, McRae emphasized the role of Buddhist terms and thoughts in his rendition, maintaining a cultural distance between the translation and its source (Chinese text).

\section{A comparative Study of the Two Translations}

In this section, I will first introduce the basic content of Chapter 6 of Vimalakirti Sutra. Then I am going to analyze the two translations of this chapter by comparing different titles, different images of the main figures, and different translations of some key concepts.

\section{A. Basic Content}

Chapter 6 talks about wisdom and expedient means possessed by the Bodhisattvas who dwell in the emancipation Beyond Comprehension (Inconceivable emancipation). The plot is unfolded dramatically. I summarize the chapter in 
the "Five-act Structure"(Freytag, 2014):

TABLE 1

FIVE-ACT STRUCTURE OF CHAPTER 6

\begin{tabular}{|l|l|}
\hline Six stages & Plots \\
\hline Initial incident (Exposition 1) & $\begin{array}{l}\text { At that time Shariputra, observing that there were no seats in } \\
\text { Vimalakirti's room, thought to himself: All these } \\
\text { bodhisattvas and major disciples_where are they going to } \\
\text { sit? }\end{array}$ \\
\hline Preliminary event (Exposition 2) & $\begin{array}{l}\text { Conversations about how to be a seeker of the Law. } \\
\text { Vimalakirti then exercised his transcendental powers to bring } \\
\text { thirty-two thousand lion seats, tall, broad, adorned, and pure } \\
\text { into his room. }\end{array}$ \\
\hline Rising action & There were none who could climb up into the seats. \\
\hline Climax & $\begin{array}{l}\text { After making obeisance to the Thus Come One Sumeru } \\
\text { Lamp King, they were able to seat themselves in the lion } \\
\text { seats. }\end{array}$ \\
\hline Falling action & $\begin{array}{l}\text { A brief description of the powers possessed by this } \\
\text { bodhisattva of the emancipation Beyond Comprehension. }\end{array}$ \\
\hline Denouement & $\begin{array}{l}\text { The compliment on the wisdom and expedient means } \\
\text { possessed by the bodhisattvas who dwell in the emancipation } \\
\text { Beyond Comprehension. }\end{array}$ \\
\hline
\end{tabular}

B. Title

The original title of Chapter 6 is “不思議品” (busiyi ping), which could be divided into two parts: “不思議” and “品.” Following the English convention, both of the two versions translated “品” into “chapter" and moved it to front of “不 思議.” With regard to “不思議,” Watson’s translation is “beyond comprehension," while McRae translated it into “inconceivable." Charles Muller(2007) made a very detailed definition of “不思議”:

Non-conceptual; inscrutable. That which is beyond contemplation or conceptualization. Beyond linguistic expression. Beyond thought and words, beyond conception, baffling description, amazing (Skt. Acintya) Transliterated as 阿軫帝 也. Usually said in reference to some quality of the Buddha's teaching, especially something that defies ordinary comparison. Also commonly written as 不可思議.

That is to say, “不思議” actually contains two layers of meanings:1) beyond conceptualization, 2) beyond and against linguistic expression. From this perspective, although Watson's "beyond comprehension" is more directly translated (beyond for “不," and comprehension for “思議”) and more readable, it only touches on one layer of the meanings. By contrast, in spite of McRae's attempt to avoid superficial translation and keep the religious interest, he provided a very stiff and awkward word here.

The format of the title is another issue should be emphasized. The chapter titles (品目 pingmu) of Chinese Buddhist texts usually have very uniform format— they follow the format of “ $A+$ 品." “A” here could be an adjective, noun, and phrase, and the “ $\mathrm{A}+$ 品” as a whole constitutes a noun-phrase. Therefore, compared to "inconceivable," "beyond comprehension" is more faithful to such a format.

C. Images of Main Figures 


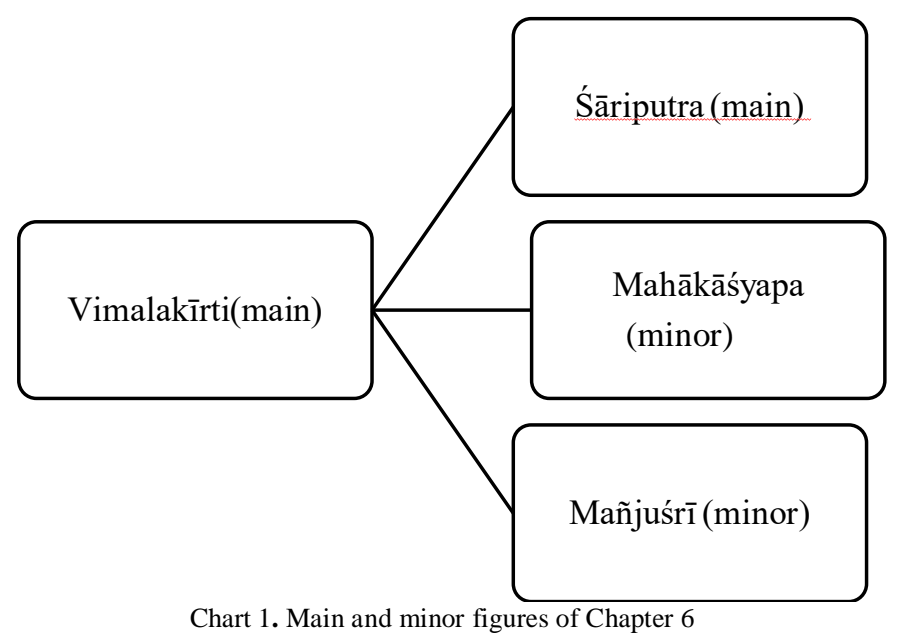

Vimalakīrti: Vimalakīrti is the protagonist of the narrative of the whole sutra and also leads all conversations in Chapter 6. Generally speaking, his persona has two sides: on the one hand, he is a devout lay Buddhist and shows his respect to Buddha, Bodhisattvas, and great disciples; on the other hand, because his spiritual attainment and transcendental powers are far greater than these of most Bodhisattvas and great disciples, in order to enlighten these Bodhisattvas and great disciples, he criticizes and even plays tricks on them. Judging from the two translations, we can see that McRae insisted on keeping balance between the two sides, while Watson intended to depict Vimalakirti as a cynical man. There are two examples:

\section{Example 1.}

Chinese version: 長者維摩詰知其意, 語舍利弗言：雲何仁者為法來耶?求床座耶? 舍利弗言：我為法來，非

為床座。(Zhonghua dian zi fo dian xie hui[FDXH],2010)

Watson (1997): The rich man Vimalakirti, knowing what was in his mind, said to Shariputra, "Did you come here for the sake of the Law, or are you just looking for a place to sit?"

"I came for the Law, not for a seat!" said Shariputra.

McRae (2004): The Elder Vimalakīrti knew what he was thinking and said to Śāriputra, "Which is it, sir—did you come for the Dharma or come seeking a seat?" Śāriputra said, "I came for the Dharma, not for a seat."

First, Watson translated “長者” into "the rich man," but McRae used "the Elder" to call Vimalakirti. Apparently, "the Elder" is an honorific title to call someone who is widely venerated, while "the rich man" seems to hint at a persona of a wealthy but impolite overnight millionaire.

Next, in regards to the word “仁者," McRae translated it into "sir"; Watson's version is "you” (or he just omitted this word). "You" is of course informal and a little impolite, considering the interlocutor is one of the most honored disciples of Buddha. However, the persona that Watson intended to depict is clearer.

\section{Example 2.}

Chinese version: 爾時, 長者維摩詰, 問文殊師利：仁者游於無量千萬億阿僧祇國，何等佛土有好上妙功德成 就師子之座?

文殊師利言：居士!東方度三十六恒河沙國，有世界名須彌相，其佛號須彌燈王，今現在。彼佛身長八萬四千 由旬，其師子座高八萬四千由旬，嚴飾第一。(FDXH, 2010)

Watson (1997): At that time the rich man Vimalakirti said to Manjushri, "You have visited countless thousands, ten thousands, billions of asamkhyas of countries. What Buddha lands have the finest and most beautiful lion seats, those endowed with the best qualities?"

Manjushri replied, "Layman, to the east, beyond countries numerous as the sands of thirty-six Ganges, lies a world called Sumeru Shape. Its Buddha is named Sumeru Lamp King, and he is there now. This Buddha's body is eighty-four thousand yojanas in height and the lion seat [he sits on] is eighty-four thousand yojanas high and adorned in the finest fashion."

McRae (2004): At this time the Elder Vimalakīrti asked Mañjuśrī, "Sir, in your wanderings throughout the immeasurable ten million koțis of incalculable numbers of [buddha] countries, which buddha land has lion seats made with the best and most wondrous qualities?"

Mañjuśrí said, "Retired scholar, in the east, as many countries away as there are grains of sand in thirty-six Ganges Rivers, there is a world-system called Characteristic of Sumeru. Its buddha is called Sumeru Lamp King, who is manifest [in that world] at present. That buddha's body is eighty-four thousand yojanas tall. His lion seat is eighty-four thousand yojanas high and paramount in ornamentation." 
Mañjuśrī is one of the most honored Bodhisattvas who personifies supreme wisdom. Even Buddha himself shows respect to Mañjuśrī and praises his wisdom. In previous chapters, he acted as the envoy of Buddha to inquire about Vimalakīrti's illness. In Watson's rendition, Vimalakīrti maintains the image of a wealthy but arrogant man and uses "you" to the call the great Bodhisattva, Mañjuśrī. In return, Mañjuśrī calls him "layman." "Layman" is a direct translation of “居士”_ a neutral, at least not a very respectful title.

One minor point. McRae's use of "retired scholar" is also a little weird. It is understandable to translate " \pm " into "scholar." But "retired” might not be an appropriate English counterpart of “居.”

Śāriputra: Śāriputra is also a two-sided character in this chapter. For one thing, he is the chief and earliest disciple of Buddha. He is also a leader of the Buddhist community and a loyal follower and practitioner of Buddhist teachings; For another, confronting the great layman Vimalakīrti, Sāriputra shows his limited spiritual attainment and transcendental powers - he is just like a not so smart student who always makes mistakes and is then criticized by the "teacher" Vimalakīrti. Again, different translation strategies are shown through the depiction of Sāriputra: one (McRae's) keeps balance and is faithful to the historical and "real" Säriputra, instead of basing his translation entirely on the text itself; the other one (Watson's) inclines to provide a vivid literary image of Śăriputra.

\section{Example 3.}

Chinese version: 爾時, 維摩詰語舍利弗 : 就師子座。舍利弗言 : 居士!此座高廣, 吾不能升。

\section{維摩詰言：唯，舍利弗!為須彌燈王如來作禮，乃可得坐。}

舍利弗言: 居士!未曾有也, 如是小室, 乃容受此高廣之座, 於毗耶離城, 無所妨礙, 又于閻浮提聚落城邑, 及四天下諸天龍王鬼神宮殿, 亦不迫迮。(FDXH, 2010)

Watson(1997): At that time Vimalakirti said to Shariputra, "Sit down in a lion seat!" But Shariputra said, "Layman, these seats are too tall and wide_-we can't climb up in them!"

Vimalakirti said, "Ah, Shariputra, if you will make obeisance to the Thus Come One Sumeru Lamp King, then you will be able to take a seat."

Shariputra said, "Layman, I have never seen such a thing! A little room like this and still it can hold seats as tall and broad as these! And the city of Vaishali is in no way crowded or obstructed, nor are any of the towns or villages of Jambudvipa or of the other of the four continents cramped or inconvenienced, or the palaces of the heavenly beings, dragon kings and spirits!"

McRae (2004): At that time Vimalakīrti said to Śāriputra, "Take a lion seat." Śāriputra said, "Retired scholar, this seat is [so] huge I am unable to ascend it." Vimalakīrti said, "O Śāriputra, after you have worshiped Sumeru Lamp King Tathāgata you will be able to sit there."

Śāriputra said, "Retired scholar, this is unprecedented! Such a small room has accommodated these huge seats, and there is no hindrance in the city of Vaiśālī, nor is there any distortion in the villages and towns of Jambudvīpa, nor in all the worlds of four continents, nor in the palaces of the gods, dragon kings, and demonic spirits."

The difference between "can't climb up in them" and "unable to ascend it" is very subtle : the former one seems to describe a mortal man or an ordinary people who possesses wishful thinking of trespassing the immortals' land; the latter one refers to a great being (an immortal) who tries to achieve something that is beyond his ability.

In addition, translating “未曾有也” into “this is unprecedented” is just a sort of compliment and still objective, but the phrase of "I have never seen such a thing" seems to be quite subjective, admitting one's being provincial and ignorant.

\section{Key Concepts}

As mentioned before, early translations might be more domesticated or target-oriented, while the later translations (retranslations as to say) tend to maintain a cultural distance between the translation and its source, which is especially true in the case of the translations of some key concepts of Chapter 6.

法:The Chinese character “法” frequently appears in Chapter 6. According to Charles Muller, “法” in the Buddhist context has a wide range of meanings: sometimes it refers to the teaching delivered by the Buddha; in other circumstances, it is used in the sense of all things(一切 yiqie), or anything small or great, visible or invisible, real or unreal, affairs, truth, principle, method, concrete things, abstract ideas, etc.(Muller, 2007). The use of “法” in our text should belong to the first category.

Watson translated it into "law," a very old-fashioned but easily understood word_—people might well catch on its literal meaning by just a glimpse of it. McRae's expression is more complicated and foreignized—he chose the Classical Sanskrit noun "dharma" as the counterpart of “法," one term that people without knowledge of Indian religions could neither understand nor pronounce, which exactly proves that as McRae indicated in his preface, the main purpose of his translation is to add more religious interest. 
不思議解脫: it is the theme of this chapter and also related to the above-mentioned chapter title. Although both of the two renditions translated “解脫” into “emancipation,” due to the different translations of “不思議,” Watson’s version is "emancipation Beyond Comprehension," and McRae's version is "inconceivable emancipation." The reason why Watson reversed the word order is unknown (the right order based on his vocabulary should be "Beyond Comprehension emancipation"), yet it is clear that he translated literally. Interestedly, despite that "inconceivable" is a stiff translation of “不思議,” McRae’s “inconceivable emancipation” is much more appropriate than Watson’s version.

阿㤽多羅三睍三菩提: A transliteration of the Sanskrit anuttara-samyak-sambodhi, which means supreme correct enlightenment. Anuttarā means unsurpassed; samyak means correct, and saṃbodhi means enlightenment (Muller,2007).

Since it is a specific Buddhist term, the two translators chose to keep it in the form of Romanized Sanskrit, anuttara-samyak-sambodhi. The only difference is that McRae directly put it there, while Watson used the phrase of "the attainment of anuttara-samyak-sambodhi," reminding readers that the term "anuttara-samyak-sambodhi" is a kind of spiritual attainment. In this way, the readers of Watson's rendition might not need to refer to a Buddhist dictionary.

\section{Conclusion}

Retranslation is a widespread phenomenon which has been discussed and studied by translators and Translation Studies scholars for years. The meaning of retranslation lies in its difference (not necessarily improvement) from the previous ones, which means retranslation would provide something new both to readers and translators. In our case, although Watson's rendition is recognized as one in high quality, McRae's work still helps us to contemplate on how to keep balance between literary interest and religious interest during the process of translating sacred texts.

In general, when later translators are not satisfied with the pre-existing renditions, they embark on their own versions. As clearly stated in the preface, the reason why McRae started his own rendition is that he was discontent with Watson's translation strategies and attempted to focus on religious interest in his work.

Driven by various concerns, early translations might be more domesticated or target-oriented, while retranslation tends to maintain a cultural distance between the translation and its source. Thus, we tend to regard Watson's work as a more faithful translation, but see McRae's rendition as a scholarly artifact.

\section{REFERENCES}

[1] Brownlie, Siobhan. (2006). Narrative theory and retranslation theory. Across Languages and Cultures 7.2, 140-170.

[2] Fang, Guangchang. (2007). Xieben zangjing de fenqi yu tedian. Wenshizhe 37.3, 68-74.

[3] Feng, Lei. (2014). Retranslation hypotheses revisited: A case study of two English translations of Sanguo Yanyi - the first Chinese novel. Stellenbosch Papers in Linguistics Plus 43.1, 69-86.

[4] Freytag, Gustav. (2014). Freytag's Technique of the Drama: An Exposition of Dramatic Composition and Art (Elias J. MacEwan,Trans.).Chicago: Scott, Foresman and Company.

[5] Gürçağlar, Şehnaz. (2009). Retranslation. In M. Baker and G. Saldana (Eds.), Routledge encyclopedia of translation studies (pp. 232-235). Abingdon: Routledge.

[6] Kumārajīiva. (1997). Vimalakīrti Sutra (Burton Watson, Trans.). New York: Columbia University Press.

[7] Kumārajīva. (2004). Vimalakīrti Sutra (John McRae, Trans.) Berkeley: Numata Center for Buddhist Translation and Research.

[8] Mair, Victor. (2012). What is Geyi, After All?. China Report 48.1, 29-59.

[9] Muller, A. Charles. (Eds.). (2007). Digital Dictionary of Buddhism. http://buddhism-dict.net/ddb (accessed 02/01/2021).

[10] Nattier, Jan. (1992). The Heart Sutra: A Chinese Apocryphal Text?. Journal of the International Association of Buddhist Studies 15.2, 153-224.

[11] Nattier, Jan. (2000). The Teaching of Vimalakīrti (Vimalakīrtinirdeśa): A Review of Four English Translations. Buddhist Literature 2.1, 234-258.

[12] Silk, Jonathan. (2015). Brill's Encyclopedia of Buddhism vol.1. Leiden: Brill.

[13] Venuti, Lawrence. (2003). Retranslations: The creation of value. Bucknell Review 47.1, 25-39.

[14] Zhonghua dian zi fo dian xie hui. (2010). Chinese electronic Tripitaka collection. Taibei: Zhonghua dian zi fo dian xie hui.

Tianyu Lei is currently a Ph.D. student in Department of East Asian Studies at the University of Arizona (Tucson). His research interests include Ming-Qing Buddhism and Buddhist literature. Other interests include Buddhist art and Chinese folklore. 